\title{
Effect of Integrated Nutrient Management on Growth, Yield, Quality and Economics of Fodder Sugar Beet (Beta vulgaris) Varieties
}

\author{
K.R. Patel* and M.M. Patel \\ N.M. College of Agriculture, Navsari Agricultural University, Navsari, Gujarat-396450, India \\ *Corresponding author
}

\begin{tabular}{|l|}
\hline Ke y w o r d s \\
Integrated nutrient \\
management, \\
Azotobacter, \\
Biofertilizer, Sugar \\
beet, Varieties, Net \\
realization, PSB, \\
Potash solubilizing \\
bacteria
\end{tabular}

\section{A B S T R A C T}

A field experiment was conducted during rabi season of 2016-17 at the College Farm, N. M. College of Agriculture, Navsari Agricultural University, Navsari to study the "Effect of integrated nutrient management on growth, yield, quality and economics of fodder sugar beet (Beta vulgaris) varieties". Total ten treatment combinations comprising of two varieties viz., $\mathrm{V}_{1}$ : JK kuber and $\mathrm{V}_{2}$ : JK magnolia and five levels of integrated nutrient management i.e. $\mathrm{F}_{1}: 100 \%$ RDF (RDF: $120: 60: 60 \mathrm{NPK} \mathrm{kg} / \mathrm{ha}$ ), $\mathrm{F}_{2}: 75 \% \mathrm{RDF}+25 \% \mathrm{~N}$ through $\mathrm{BC}, \mathrm{F}_{3}: 75 \% \mathrm{RDF}+25 \% \mathrm{~N}$ through $\mathrm{BC}+$ bio-fertilizer (Azotobacter + PSB + Potash solubilizing bacteria, $10^{8} \mathrm{CFU} / \mathrm{ml}, 1.25$ lit/ha each), $\mathrm{F}_{4}: 50 \% \mathrm{RDF}+50 \% \mathrm{~N}$ through $\mathrm{BC}$ and $\mathrm{F}_{5}: 50 \% \mathrm{RDF}+50 \% \mathrm{~N}$ through $\mathrm{BC}+$ bio-fertilizer (Azotobacter $+\mathrm{PSB}$ + Potash solubilizing bacteria, $10^{8} \mathrm{CFU} / \mathrm{ml}, 1.25 \mathrm{lit} / \mathrm{ha}$ each) were evaluated in factorial randomized block design with four replications. Significantly improved plant height, number of leaves per plant, dry matter accumulation per plant, root length and fresh foliage yield was observed in $\mathrm{JK}$ magnolia $\left(\mathrm{V}_{2}\right)$, while root weight, fresh root yield and total fresh biomass yield were significantly higher in JK kuber $\left(\mathrm{V}_{1}\right)$. All the growth and yield parameters viz., plant height, number of leaves per plant, dry matter accumulation per plant, root length, root weight as well as yield such as fresh root yield, fresh foliage yield and total fresh biomass were significantly influenced due to integrated nutrient management. All these parameters beared higher values with application of $50 \% \mathrm{RDF}+$ $50 \% \mathrm{~N}$ through $\mathrm{BC}+$ bio-fertilizer $\left(\mathrm{F}_{5}\right)$ followed by $75 \% \mathrm{RDF}+25 \% \mathrm{~N}$ through $\mathrm{BC}+$ bio-fertilizer $\left(\mathrm{F}_{3}\right)$. Maximum net realization $\left(\square 108353 \mathrm{ha}^{-1}\right)$ and BCR (3.14) were registered under JK kuber $\left(\mathrm{V}_{1}\right)$ followed by JK magnolia $\left(\mathrm{V}_{2}\right)$ with net realization of $\square$ $98119 \mathrm{ha}^{-1}$ and BCR of 2.94. Whereas looking to the integrated nutrient management, application of $50 \% \mathrm{RDF}+50 \% \mathrm{~N}$ through $\mathrm{BC}+$ bio-fertilizer $\left(\mathrm{F}_{5}\right)$ accrued the maximum net realization of $\square 114897 \mathrm{ha}^{-1}$ and BCR of 3.25 followed by application of $75 \% \mathrm{RDF}+$ $25 \% \mathrm{~N}$ through $\mathrm{BC}+$ bio-fertilizer $\left(\mathrm{F}_{3}\right)$ with net realization of $\square 110147$ ha $^{-1}$ and BCR of 3.17 .

\section{Introduction}

India supports nearly 20 per cent of the world's livestock being the leader in cattle $(16 \%)$, buffalo $(55 \%)$, goat $(20 \%)$ and sheep (5\%) population. The livestock sector contributes 32 per cent of the agricultural output which is 22 per cent of the total GDP in India. Deficiency in feed and fodder has been identified as one of the major component in achieving the desired level of livestock production. The shortage in dry fodder is 21.8 
per cent compared with requirement of 560 million tones for the current livestock populations (Anonymous, 2009). The low productivity and poor performance of the livestock are mainly due to unavailability of nutritious fodder in sufficient quantity. The availability of nutritious fodder is inadequate in the country. India faces a net deficit of 61 percent green fodder, 21.9 percent dry crop residues and 64 percent feed. The most important constraints in the fodder production and productivity are the non-availability of improved variety of fodder crop.

Sugar beet (Beta vulgaris) belonging to family Amaranthaceae, is a biennial crop grown for its fleshy and swollen roots. It is being cultivated in many parts of the world for sugar, fodder and vegetable purpose. It can be successfully grown as a fodder crop and used as valuable source of green fodder. The high crude protein and sugar content makes it more palatable, nutritious and energy feed and having a good scope for livestock industry in India. However, its cultivation in India as fodder crop is not common. The objective of the present study was to evaluate the effect of integrated nutrient management on growth, yield and quality of fodder sugar beet varieties.

\section{Materials and Methods}

A field experiment was conducted during rabi season of 2016-17 at the College Farm, N. M. College of Agriculture, Navsari Agricultural University, Navsari. Geographically, Navsari is situated at $20^{\circ} 57^{\prime}$ North latitude, $72^{\circ} 54^{\prime}$ East longitudes and has an altitude of 10 meters above the mean sea level. It is located $12 \mathrm{~km}$ away in the East from the great historical place "Dandi" on the Arabian seashore. The soil of the experimental plot was clayey in texture and slightly alkaline in reaction ( $\mathrm{pH}: 8.14$ ), low in available nitrogen $(231 \mathrm{~kg} / \mathrm{ha})$, moderately high in available phosphorus $(37 \mathrm{~kg} / \mathrm{ha})$, fairly rich in available potassium $(458 \mathrm{~kg} / \mathrm{ha})$ and moderately high in organic carbon $(0.72 \%)$.

A field experiment was laid out in factorial randomized block design with four replications, comprising of two varieties viz., $\mathrm{V}_{1}$ : JK kuber and $\mathrm{V}_{2}$ : JK magnolia and five levels of integrated nutrient management i.e., $\mathrm{F}_{1}: 100 \%$ RDF (RDF: $120: 60: 60$ NPK kg/ ha), $\mathrm{F}_{2}: 75 \% \mathrm{RDF}+25 \% \mathrm{~N}$ through $\mathrm{BC}, \mathrm{F}_{3}$ : $75 \% \mathrm{RDF}+25 \% \mathrm{~N}$ through $\mathrm{BC}+$ biofertilizer (Azotobacter + PSB + Potash solubilizing bacteria, $10^{8} \mathrm{CFU} / \mathrm{ml}, 1.25 \mathrm{lit} / \mathrm{ha}$ each), $\mathrm{F}_{4}: 50 \% \mathrm{RDF}+50 \% \mathrm{~N}$ through $\mathrm{BC}$ and $\mathrm{F}_{5}: 50 \% \mathrm{RDF}+50 \% \mathrm{~N}$ through $\mathrm{BC}+$ bio-fertilizer (Azotobacter + PSB + Potash solubilizing bacteria, $10^{8} \mathrm{CFU} / \mathrm{ml}, 1.25 \mathrm{lit} / \mathrm{ha}$ each).

Sowing of fodder sugar beet was done manually at $45 \times 20 \mathrm{~cm}$ spacing on raised beds (60 $\mathrm{cm}$ breadth $\mathrm{x} 20 \mathrm{~cm}$ depth). The recommended fertilizer dose (100\% RDF) of $\mathrm{N}, \mathrm{P}$ and $\mathrm{K}$ was 120,60 and $60 \mathrm{~kg} / \mathrm{ha}$ respectively, of which half dose of $\mathrm{N}$ and full dose of $\mathrm{P}$ and $\mathrm{K}$ were applied as basal while remaining half dose of $\mathrm{N}$ was applied in two equal splits at 45 and 90 DAS as per treatments.

Nitrogen, phosphorus and potash were supplied through urea, single super phosphate and muriate of potash, respectively. Bio compost was applied on the basis of $\mathrm{N}$ content as per treatment at 20 days before sowing. Biofertilizer (Azotobacter, PSB and Potash solubilizing bacteria) were applied as seed inoculation at $24 \mathrm{hrs}$ before sowing as per the treatments. All other recommended practices were followed. The data recorded for different parameters were statistically analysed with the help of analysis of variance (ANOVA) technique for a factorial randomised block design. 


\section{Results and Discussion}

\section{Growth and yield attributes}

Growth and yield parameters viz., plant height, number of leaves per plant, dry matter accumulation per plant, root length and root weight were significantly influenced by different varieties (Table 1). JK magnolia $\left(\mathrm{V}_{2}\right)$ recorded significantly higher value for plant height, number of leaves per plant, dry matter accumulation per plant and root length as compared to JK kuber $\left(\mathrm{V}_{1}\right)$. While root weight was significantly higher in JK kuber $\left(\mathrm{V}_{1}\right)$. The difference in growth and yield attributes might be due to genetic make-up of plant itself. These findings are in close agreement with those reported by Sanghera et al., (2016).

Significant difference was observed among integrated nutrient management for growth and yield attributes (Table 1). Application of $50 \% \mathrm{RDF}+50 \% \mathrm{~N}$ through $\mathrm{BC}+$ biofertilizer $\left(\mathrm{F}_{5}\right)$ produced significantly higher plant height, which was statistically at par with $75 \% \mathrm{RDF}+25 \% \mathrm{~N}$ through $\mathrm{BC}+$ biofertilizer $\left(\mathrm{F}_{3}\right)$ and $50 \% \mathrm{RDF}+50 \% \mathrm{~N}$ through BC $\left(\mathrm{F}_{4}\right)$. Number of leaves per plant, dry matter accumulation per plant, root length and root weight were recorded significantly higher under $50 \% \mathrm{RDF}+50 \% \mathrm{~N}$ through $\mathrm{BC}$ + bio-fertilizer $\left(\mathrm{F}_{5}\right)$ but it remained statistically at par with $75 \% \mathrm{RDF}+25 \% \mathrm{~N}$ through $\mathrm{BC}+$ bio-fertilizer $\left(\mathrm{F}_{3}\right)$.

\section{Yield}

Significant differences in fresh root yield, fresh foliage yield and total fresh biomass yield were recorded due to varieties and integrated nutrient management (Table 2). Among the two varieties, JK kuber $\left(\mathrm{V}_{1}\right)$ produced significantly higher fresh root yield (38.33 t/ha) and total fresh biomass yield (52.99 t/ha) as compared to the JK magnolia $\left(\mathrm{V}_{2}\right)$. Increased value of fresh root yield and total fresh biomass yield was attributed to higher value of root weight. In case of fresh foliage yield, JK magnolia $\left(\mathrm{V}_{2}\right)$ produced significantly higher (16.67 t/ha) as compared to JK kuber $\left(\mathrm{V}_{1}\right)$. This results might be due to overall improvement in vegetative growth as evidenced by higher plant height and number of leaves due to its genetic character of faster canopy development. These results are in line with those reported by Singh and Grag (2013).

Among the integrated nutrient management, application of $50 \% \mathrm{RDF}+50 \% \mathrm{~N}$ through $\mathrm{BC}+$ bio-fertilizer $\left(\mathrm{F}_{5}\right)$ being statistically at par with $75 \% \mathrm{RDF}+25 \% \mathrm{~N}$ through $\mathrm{BC}+$ bio-fertilizer $\left(\mathrm{F}_{3}\right)$ and $50 \% \mathrm{RDF}+50 \% \mathrm{~N}$ through $\mathrm{BC}\left(\mathrm{F}_{4}\right)$,produced significantly higher fresh root yield (38.28 t/ha), fresh foliage yield (17.06 t/ha)and total biomass yield (55.34 t/ha). This might be due to adequate supply of nutrient from inorganic fertilizers with use of organic manure and bio-fertilizers. Bio-compost contains more essential plant nutrients, vitamin, hormones, enzymes and other beneficial microbes etc. had better effect on yield attributes due to improvement in the soil fertility. It also releases the nutrients slowly for the benefits of crop during entire crop growth period. These findings are in agreement with Bhullar et al., (2010).

\section{Quality}

Varieties did not exert significant influence on crude protein content in root and foliage of fodder sugar beet (Table 1). Maximum crude protein content in root $(4 \%)$ and foliage (13 $\%$ ) was observed under JK magnolia $\left(\mathrm{V}_{2}\right)$ and JK kuber $\left(\mathrm{V}_{1}\right)$, respectively. This might be due to better availability of nitrogen to different plant parts. While, integrated nutrient management has exert significant improvement on crude protein content in root and foliage of fodder sugarbeet (Table 1). Application of $50 \% \mathrm{RDF}+50 \% \mathrm{~N}$ through $\mathrm{BC}+$ bio-fertilizer $\left(\mathrm{F}_{5}\right)$ recorded significantly higher crude protein in root and foliage (4.18 and 13.59 per cent, respectively) 
Table.1 Effect of integrated nutrient management on growth, yield attributes and quality of fodder sugar beet varieties

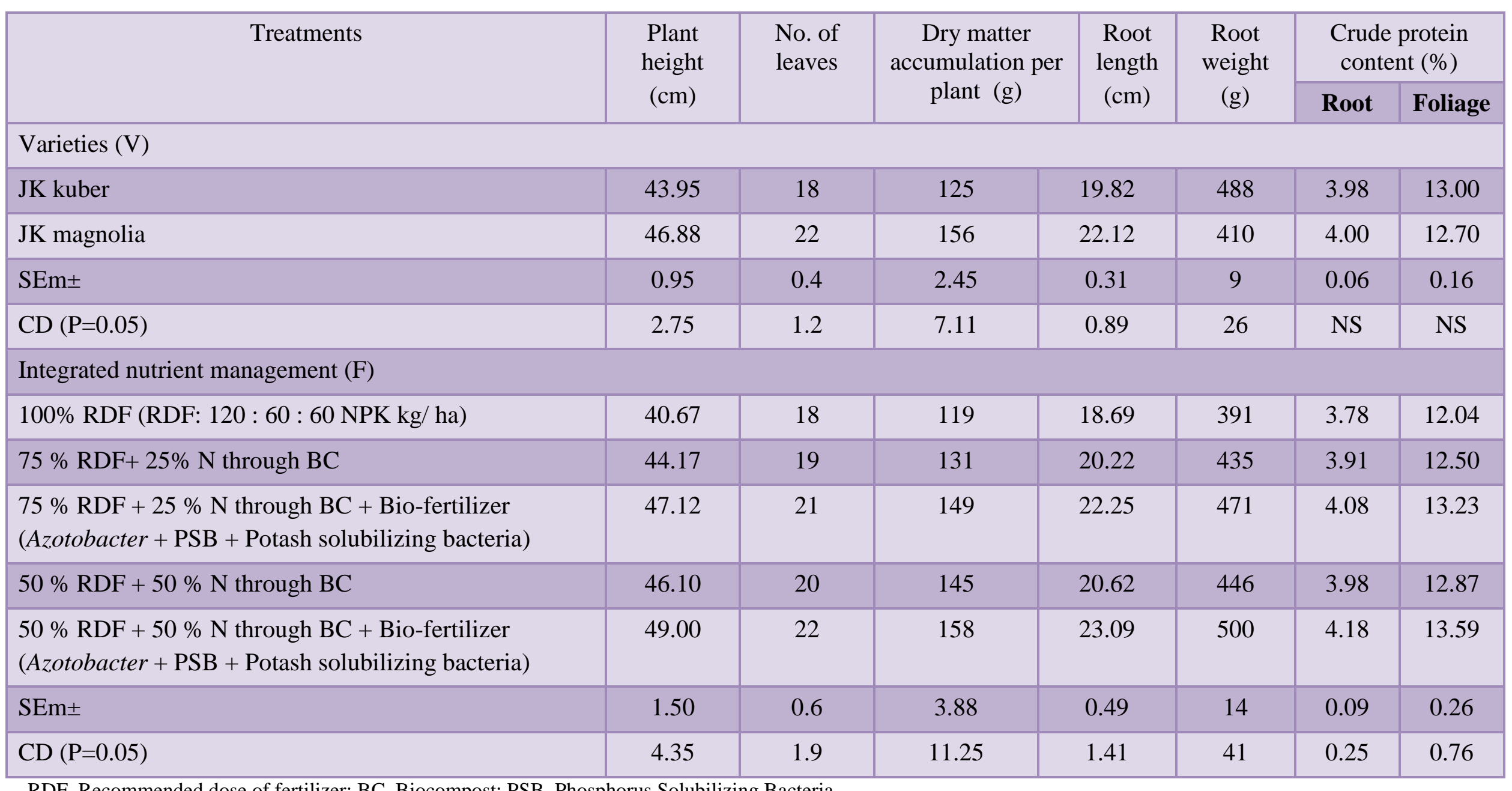

RDF, Recommended dose of fertilizer; BC, Biocompost; PSB, Phosphorus Solubilizing Bacteria 
Table.2 Effect of integrated nutrient management on yield and economics of fodder sugar beet varieties

\begin{tabular}{|c|c|c|c|c|c|c|}
\hline \multirow[t]{2}{*}{ Treatments } & \multicolumn{3}{|c|}{ Yield (t/ha) } & \multirow{2}{*}{$\begin{array}{c}\text { Gross } \\
\text { realization } \\
\text { ( } \square / \mathrm{ha})\end{array}$} & \multirow{2}{*}{$\begin{array}{c}\text { Net } \\
\text { realization } \\
\text { ( } \square / \mathrm{ha})\end{array}$} & \multirow{2}{*}{$\begin{array}{l}\mathrm{B}: \mathrm{C} \\
\text { ratio }\end{array}$} \\
\hline & $\begin{array}{c}\text { Fresh } \\
\text { root }\end{array}$ & $\begin{array}{l}\text { Fresh } \\
\text { foliage }\end{array}$ & $\begin{array}{c}\text { Total fresh } \\
\text { Biomass }\end{array}$ & & & \\
\hline \multicolumn{7}{|l|}{ Varieties (V) } \\
\hline JK magnolia & 32.92 & 16.67 & 49.58 & 148749 & 98119 & 2.94 \\
\hline SEm \pm & 8.98 & 3.50 & 9.54 & -- & -- & -- \\
\hline 100\% RDF (RDF: $120: 60: 60$ NPK kg/ ha) & 32.03 & 14.00 & 46.03 & 138085 & 87998 & 2.76 \\
\hline $75 \% \mathrm{RDF}+25 \% \mathrm{~N}$ through $\mathrm{BC}$ & 34.05 & 15.50 & 49.54 & 148632 & 98217 & 2.95 \\
\hline $\begin{array}{l}75 \% \mathrm{RDF}+25 \% \mathrm{~N} \text { through } \mathrm{BC}+\text { Bio-fertilizer } \\
\text { (Azotobacter }+\mathrm{PSB}+\text { Potash solubilizing bacteria) }\end{array}$ & 37.57 & 16.08 & 53.65 & 160936 & 110147 & 3.17 \\
\hline $50 \% \mathrm{RDF}+50 \% \mathrm{~N}$ through $\mathrm{BC}$ & 36.20 & 15.69 & 51.89 & 155663 & 104920 & 3.07 \\
\hline
\end{tabular}

RDF, Recommended dose of fertilizer; BC, Biocompost; PSB, Phosphorus Solubilizing Bacteria 
It was statistically at par with $75 \% \mathrm{RDF}+25$ $\% \mathrm{~N}$ through $\mathrm{BC}+$ bio-fertilizer $\left(\mathrm{F}_{3}\right)$ and 50 $\% \mathrm{RDF}+50 \% \mathrm{~N}$ through $\mathrm{BC}\left(\mathrm{F}_{4}\right)$. The improvement in crude protein content in root and foliage due to combined effect of inorganic fertilizer, organic manure and biofertilizer which may increase by nitrogen content in root and foliage. These results are in conformity with the finding of Yadav et al., (2007) and shekara et al., (2009) in fodder sorghum

\section{Economics}

The economic parameters for fodder sugar beet were calculated and presented in Table 2 . Among two varieties, JK kuber $\left(\mathrm{V}_{1}\right)$ secured maximum net realization of $\square 108353 \mathrm{ha}^{-1}$ and BCR value of 3.14 followed by JK magnolia $\left(\mathrm{V}_{2}\right)$ with net realization of $\square 98119$ $\mathrm{ha}^{-1}$ and BCR value of 2.94. In case of integrated nutrient management, maximum net return of $\square 114897 \mathrm{ha}^{-1}$ and BCR value of 3.25 were achieved with application of $50 \%$ $\mathrm{RDF}+50 \% \mathrm{~N}$ through $\mathrm{BC}+$ bio-fertilizer $\left(\mathrm{F}_{5}\right)$ followed by application of $75 \% \mathrm{RDF}+$ $25 \% \mathrm{~N}$ through $\mathrm{BC}+$ bio-fertilizer $\left(\mathrm{F}_{3}\right)$ with net return of $\square 110147 \mathrm{ha}^{-1}$ and BCR with 3.17 .

On the basis of results obtained in present investigation, it can be concluded that for achieving higher yield, profitability and quality of fodder sugar beet with lowest cost of cultivation, variety $\mathrm{JK}$ kuber should be grown with application of $50 \%$ RDF (RDF: $\left.120: 60: 60 \mathrm{~N}, \mathrm{P}_{2} \mathrm{O}_{5}, \mathrm{~K}_{2} \mathrm{O} \mathrm{kg} \mathrm{ha}{ }^{-1}\right)+50 \% \mathrm{~N}$ through bio-compost.

\section{References}

Anonymous 2009. Hand Book of Agriculture (Indian Council of Agricultural Research), New Delhi-110 012.

Bhullar, M. S., Uppal, S. K. and Kapur, M. L. 2009. Effect of agronomic practices and varieties on productivity of sugarbeet (Beta vulgaris L.) in semiarid region of Punjab. J. Res. Punjab agric. Univ. 46: 6-8.

Sanghera, G. S., Singh, R. P., Kashyap, L., Tyagi, V. and Sharma, B. 2016.Evaluation of sugar beet genotypes (Beta vulgaris L.) for root yield and quality traits under subtropical conditions. J. Krishi Vigyan, 5(1): 67-73.

Shekara, B. J., Lohithaswa, H. C. and Pavan, R. 2009. Effect of different sources of nutrients on green forage yield and quality of multicut fodder sorghum (Sorghum bicolor L. Moench). Forage Res., 35(3): 137-142.

Singh, D. and Garg, A. K. 2013. Fodder beetA promising fodder crop for dairy animals. Indian Farming 61(10): 1013.

Yadav, P. C., Sadhu, A. C. and Swarnkar, P. K. 2007. Yield and quality of forage sorghum (Sorghum sudanense) as influenced by the integrated $\mathrm{N}$ management. Indian J. Agron., 52: 330- 334.

\section{How to cite this article:}

Patel, K.R. and Patel, M.M. 2019. Effect of Integrated Nutrient Management on Growth, Yield, Quality and Economics of Fodder Sugar Beet (Beta vulgaris) Varieties. Int.J.Curr.Microbiol.App.Sci. 8(01): 77-82. doi: https://doi.org/10.20546/ijcmas.2019.801.010 